\title{
Hydrothermal faunal assemblages and habitat characterisation at the Eiffel Tower edifice (Lucky Strike, Mid-Atlantic Ridge)
}

\author{
Daphne Cuvelier ${ }^{1,{ }^{*}}$, Pierre-Marie Sarradin ${ }^{2}$, Jozée Sarrazin ${ }^{2}$, Ana Colaço $^{1}$, Jon T. Copley ${ }^{3}$, Daniel \\ Desbruyères ${ }^{2}$, Adrian G. Glover ${ }^{4}$, Ricardo Serrão Santos ${ }^{1}$, Paul A. Tyler ${ }^{3}$
}

\footnotetext{
${ }^{1}$ IMAR \& Department of Oceanography and Fisheries, University of the Azores, Horta, Portugal

${ }^{2}$ Institut Français de Recherche pour l'Exploitation de la Mer (Ifremer), Centre de Brest, Département Études des Ecosystèmes Profonds, Laboratoire Environnement Profond, Plouzané, France

${ }^{3}$ School of Ocean \& Earth Science, University of Southampton, Southampton, UK

${ }^{4}$ Zoology Department, The Natural History Museum, London, UK
}

*: Corresponding author : Daphne Cuvelier, email address : daphne.cuvelier@gmail.com

\begin{abstract}
:
The Eiffel Tower edifice is situated in the Lucky Strike hydrothermal vent field at a mean depth of $1690 \mathrm{~m}$ on the Mid-Atlantic Ridge (MAR). At this 11-m-high hydrothermal structure, different faunal assemblages, varying in visibly dominant species (mussels and shrimp), in mussel size and in density of mussel coverage, were sampled biologically and chemically. Temperature and sulphide $(\Sigma S)$ were measured on the different types of mussel-based assemblages and on a shrimp-dominated assemblage. Temperature was used as a proxy for calculating total concentrations of $\mathrm{CH}_{4}$. Based on the physico-chemical measurements, two microhabitats were identified, corresponding to (i) a more variable habitat featuring the greatest fluctuations in environmental variables and (ii) a second, more stable, habitat. The highest temperature variability and the highest maximum recorded temperatures were found in the assemblages visibly inhabited by alvinocaridid shrimp and dense mussel beds of large Bathymodiolus azoricus, whereas the less variable habitats were inhabited by smaller-sized mussels with increasing bare surface in between. Larger mussels appeared to consume more $\Sigma \mathrm{S}$ compared with smaller-sized $(<1 \mathrm{~cm})$ individuals and thus had a greater influence on the local chemistry. In addition, the mussel size was shown to be significantly positively correlated to temperature and negatively to the richness of the associated macrofauna. The presence of microbial mats was not linked to specific environmental conditions, but had a negative effect on the presence and abundance of macro-fauna, notably gastropods. Whereas some taxa or species are found in only one of the two microhabitats, others, such as polychaetes and Mirocaris shrimp, cross the different microhabitats. Temperature was proposed to be a more limiting factor in species distribution than $\Sigma S$.
\end{abstract}

Keywords : Faunal assemblage ; hydrothermal vent ; microhabitat ; Mid-Atlantic Ridge ; physicochemical characterisation 


\section{Introduction}

Hydrothermal ecosystems are extremely variable environments, characterised by elevated temperatures relative to ambient deep-sea water. However, with only a few exceptions, the temperatures most vent species live at are no different from those in shallow-water habitats and it is the chemistry and composition of the fluids that sustain life at hydrothermal vents (Jannasch 1985). Steep thermal and chemical gradients exist and turbulent mixing occurs between the hydrothermal fluids and cold surrounding seawater, resulting in high local variability, on a scale of a few centimetres (Johnson et al. 1988a; Chevaldonné et al. 1991; Sarrazin et al. 1999, 2006; Le Bris et al. 2006). The region wherein sulphide and oxygen coexist, both indispensable for chemosynthesis by thiotrophic endosymbionts, is thus restricted to the interface between reduced chemicals from the hydrothermal fluids and oxygenated seawater (Johnson et al. 1988b; Sarradin et al. 2009). Attempts to define the microhabitats where species live and characterise the local faunal composition have taken place at hydrothermal vents on various Mid-Ocean Ridges and spreading centres: the East Pacific Rise (EPR: Fisher et al. 1988; Johnson et al. 1988b, 1994; Sarradin et al. 1998; Bates et al. 2005; Dreyer et al. 2005; Govenar et al. 2005; Sarrazin et al. 2006; Mills et al. 2007; Lutz et al. 2008; Matabos et al. 2008); the Juan de Fuca Ridge (JdF: Sarrazin \& Juniper 1999; Sarrazin et al. 1999; Tsurumi \& Tunnicliffe 2003; Urcuyo et al. 2003); Lau Basin (Henry et al. 2008; Podowski et al. 2009); and the Mid-Atlantic Ridge (MAR: Sarradin et al. 1999; Desbruyères et al. 2000, 2001). Evidence for the close association of vent community development with physico-chemical conditions has already been demonstrated (Luther et al. 2001). According to changing physico-chemical conditions, hydrothermal vent edifices may be inhabited by faunal assemblages that form repeating mosaics (Sarrazin et al. 1997, 1999). 
69 The Eiffel Tower edifice of the Lucky Strike vent field (1690m depth) is located on the shallower part of the MAR. It is visibly dominated by Bathymodiolus azoricus that forms extensive mussel beds (Desbruyères et al., 2001). A variety of taxa live in association with these mussel beds, including alvinocaridid shrimps and a decapod crab along with less conspicuous fauna such as polychaetes, gastropods, amphipods and pycnogonids etc. (Desbruyères et al., 2006). At the Eiffel Tower hydrothermal edifice, Cuvelier et al. (2009) identified 4 visibly different faunal assemblages of which 2 had a sub-form. Assemblage 1 was visibly dominated by dense beds of larger-sized mussels, while Assemblage 2a featured mussel clumps with bare surface in between. Assemblage 2b was similar to Assemblage 2a but contained visible microbial mats. Assemblage 3 represented bare surfaces colonised by shrimps. Assemblage 4a resembled bare substrata with small dispersed mussels, whereas Assemblage 4b was similar to Assemblage 4a but with visible microbial mats.

Using image analysis, a faunal zonation model around a fluid exit has been proposed for the Eiffel Tower edifice (Cuvelier et al., 2009). Based on the distribution patterns and proximity to the fluid exits of the faunal assemblages, the existence of at least two microhabitats was hypothesised. These microhabitats were thought to correspond to a "harsher" (higher temperature, higher sulfide) environment, inhabited by shrimps and larger-sized mussels, while the other assemblages, featuring smaller-sized mussels and a less dense coverage, were thought to be characterised by lower levels of $\mathrm{T}^{\circ} \mathrm{C}$ and sulfide. However, since this model was primarily based on video imagery, it requires confirmation through biological sampling. Hence the primary objectives of this study are: (a) to examine macrofaunal composition in visibly different assemblages, (b) to identify the microhabitats inhabited by the different faunal assemblages, (c) to evaluate if variability in physico-chemical factors corresponds to visible faunal differences (size of mussels, presence of microbial cover and species composition/dominance) and (d) to analyse if the microhabitats identified correspond to the previously hypothesised microhabitats. 
101 Lucky Strike is a basalt-hosted vent field (Langmuir et al., 1997; Fouquet et al., 1998, Ondréas et al., 2009) situated on the shallow part of the MAR, at a mean depth of 1700m, and was visually observed for the first time in 1993 (Fig. 1). It is characterised by a central lava lake, around which the hydrothermal vent edifices are located (Ondréas et al., 2009). The Eiffel Tower sulfide structure is situated in the south-eastern sector, on the saddle between two volcanic cones. It is an 11m high active edifice and one of the most visited sites within this vent field.

\section{Faunal assemblage sampling}

110 During the MoMAR08 cruise (August 2008, NO l'Atalante), semi-quantitative biological samples were taken with the Remotely Operated Vehicle (ROV) Victor 6000 on visibly different assemblages, which correspond to those identified by Cuvelier et al. 2009 (Fig. 2). Biological sampling was undertaken to investigate the macrofaunal species composition of these assemblages. To facilitate the description of the results, we will refer to the samples taken with the name of the assemblages they correspond to. Accessibility and manoeuvring space for the ROV were prime determinants in choosing a sampling location. Samples (three to four grabs) were taken with the manipulator arm of the ROV and placed in a sampling box, followed by a clearing of the sampled surface with the slurp gun/suction sampler. The faunal sampling of Assemblage 4b failed due to a hydraulic problem of the ROV, and was therefore left out of the analyses.

When the biological samples arrived on board, the macro-and megafauna received the highest attention and organisms were immediately identified to the lowest taxonomic level possible. Specimens were subsequently fixed in seawater buffered formalin (10\%) and after 48 hours transferred to $70 \%$ ethanol. The surfaces sampled were measured with pixel-based image analysis software IPLAB Spectrum ${ }^{\circledR}$ as described in Sarrazin et al. (1997), in which the manipulator arm of the ROV was used as a scale (Table 1). The crab Segonzacia mesatlantica was not considered in the statistical analysis, because this species is highly mobile and tends to escape when approached with sampling equipment, hence it could not be considered representative. Finally, the empty gastropod shells of Shinkailepas briandi present in two different samples were noted in the density table but were not considered in the statistical 
analyses, since these appeared to be remnants of a senescent population. Chemical sampling was carried out in a consecutive dive.

\section{Chemical sampling}

The CHEMINI (CHEmical MINIaturised) analyser was used to measure in situ concentrations of sulfides among the fauna (Vuillemin et al., 2009). The inlet of the analyser was directly mounted on the temperature probe manipulated by the ROV Victor 6000. Hence temperature and total dissolved sulfides $\left(\sum \mathrm{S}=\mathrm{H}_{2} \mathrm{~S}, \mathrm{HS}^{-}, \mathrm{S}^{2-}\right)$, hereafter referred to as $\Sigma \mathrm{S}$, were measured during 10 minutes among the different assemblages. Chemical sampling was carried out in an undisturbed region of each sampled assemblages. A reference sample was taken away from the hydrothermal active area, to calibrate the sensor against bottom seawater. Calibration of the analyser was done in situ, at the beginning and at the end of the dive. Sampling time stamps were noted during the dive and afterwards measurement results were refined by looking at the video imagery. Data from when the CHEMINI probe was not touching the fauna (due to involuntary ROV movements caused by currents) were eliminated to avoid measurements of surrounding seawater. Total concentrations of $\mathrm{CH}_{4}$ were calculated from these in situ values, using a $\mathrm{T}^{\circ} \mathrm{C}$ vs. $\mathrm{CH}_{4}$ regression curve obtained for Eiffel Tower hydrothermal fluids during the same cruise (Sarradin et al., in prep.).

\section{Statistics}

Principal Component Analysis (PCA) was carried out with the Vegan package (Oksanen et al., 2008) in R (version 2.8, Multicore team 2008) based on species abundance data. The species abundance-matrix was subject to a Hellinger-transformation prior to statistical analyses. Hellinger transformation is calculated by taking the square root of observed values divided by the row (site) totals and is very useful for community data, making them suitable for linear ordinations (Legendre \& Gallagher, 2001). Taxonomic richness and rarefaction were also calculated with the Vegan package, while Spearman Rank Correlations among the chemical factors were carried out in Statistica 6 (StatSoft Inc. 2001). Preference was given to Spearman Rank Correlations as these are less sensitive to outliers and do not require normality of the data. As the data matrix did not meet the assumptions for parametric testing, not even after transformations, differences between the environmental variables ( $\mathrm{T}^{\circ} \mathrm{C}$ and $\sum \mathrm{S}$ ) were analysed with non-parametric tests (Kruskal-Wallis followed by post-hoc Wilcoxon pairwise testing), which were performed in $\mathrm{R}$. Since $\mathrm{CH}_{4}$ was estimated based on the temperature values, it was not used in the statistical analyses. 


\section{Faunal assemblage sample composition}

168 The visible assemblage identification at Eiffel Tower is given in Figure 2, while an overview

169 of the fauna present in the sampled assemblages is presented in Table 1 . The density data 170 showed that samples from Assemblages 2a and 4a were dominated by the same three species, 171 starting with Bathymodiolus azoricus, the gastropods Protolira valvatoides and Lepetodrilus 172 atlanticus and the polynoid polychaete Branchipolynoe seepensis. Assemblage 1 was also 173 dominated by $B$. azoricus but the second dominant species was the shrimp Mirocaris 174 fortunata, followed by B. seepensis and Amathys lutzi polychaetes. Assemblage 3 was almost 175 exclusively dominated by Mirocaris fortunata, which were also very abundant in Assemblage 176 2b. The second dominant species for both assemblages was the amphipod Luckia striki, 177 together with an undetermined polynoid polychaete in Assemblage 3. Luckia striki had the 178 highest abundance in Assemblage 2b.

179 The mytilid individuals showed significant differences in mussel lengths (Kruskall Wallis, $180 \mathrm{H}=41.71, \mathrm{p}<0.001, \mathrm{df}=3$ ). Assemblages $2 \mathrm{a}$ and $2 \mathrm{~b}$ measured between 2 and $5 \mathrm{~cm}$ (no 181 significant differences between them, but significantly different from Assemblages 1 and 4a $182 \mathrm{p}<0.05$ ) while the mean size of the individuals in Assemblage 4a was about $1 \mathrm{~cm}$ 183 (significantly different from Assemblages 1 and 2, $\mathrm{p}<0.05$ ). The mussel length in Assemblage 1841 was significantly higher $(\mathrm{p}<0.001)$, with a mean of $6 \mathrm{~cm}$. The size or length distribution of 185 the mussels was as follows: Assemblage 4a $<$ Assemblages $2<$ Assemblage 1 . There were no 186 mussels in Assemblage 3. Gastropods were only present in the assemblages with smaller to 187 medium-sized mussels without visible microbial cover (Assemblages 2a and 4a), while 188 polychaetes had the highest abundance in the larger-sized mussel beds (Assemblage 1). 189 Branchipolynoe seepensis lives inside the mussel shells of B. azoricus. This commensal 190 polychaete had the lowest abundance when the size of the mussels was smallest (i.e. in 191 Assemblage 4a), however its abundance did not increase in proportion to the mussel shell 192 size. The ratio of the number of $B$. seepensis/number of mussels was highest in the medium193 sized mussels of Assemblage $2 \mathrm{~b}$ followed by Assemblage 1 with the larger mussels. 194 Assemblage 4a had a unique presence of the pycnogonid Sericosura heteroscela. The crab 195 Segonzacia mesatlantica was present in 3 samples: 4 individuals were sampled in Assemblage 196 1, 2 in Assemblage 2b and 2 in Assemblage 3. 
198 Taxonomic richness and rarefaction were calculated to evaluate which sample of which 199 assemblage was the most diverse (Table 1). The highest richness was found in Assemblage 4a 200 with 11 taxa present, while Assemblage 3 was the least diverse (Table 1). In these 201 calculations the undetermined species also counted as species, as they were different from the determined species. When calculating the expected number of species (Es) present in a subsample of size 100 (rarefaction or Es(100)), similar trends were apparent (Table 1). Mussel sizes showed negative relationships with taxonomic richness $\left(\mathrm{R}^{2}=0.67\right)$ and $\operatorname{Es}(100)$ $205 \quad\left(\mathrm{R}^{2}=0.81\right)$.

\section{Physical and chemical characterisation}

208 Overall, a narrow temperature range $\left(<2^{\circ} \mathrm{C}\right)$ was observed between the different assemblages 209 (Fig. 3). However, some variability was noticeable as the temperature tended to oscillate, 210 resulting in a broader temperature range for certain assemblages (Fig. 3). The minimum 211 temperature measured was $4.44^{\circ} \mathrm{C}$ in Assemblage $2 \mathrm{~b}$, i.e. very close to the seawater 212 temperature $\left(4.4^{\circ} \mathrm{C}\right)$ (Table 2). The highest temperature $\left(9.54^{\circ} \mathrm{C}\right)$ was measured in 213 Assemblage 3 (Table 2). The shrimp assemblage (Assemblage 3) thus tolerated the highest 214 temperatures recorded and the highest degree of temperature fluctuations (up to $\sim 4.4^{\circ} \mathrm{C}$ ), 215 while both Assemblages 4a and 4b were very stable, exhibiting the lowest degree of 216 fluctuations (Fig. 3). Of the mussel-based assemblages, Assemblage 1 with the larger-sized 217 mussels had the broadest range $\left(\sim 1.56^{\circ} \mathrm{C}\right)$ and the highest maximum temperature $\left(6.14^{\circ} \mathrm{C}\right)$ 218 (Fig. 3).

Among the different environmental factors, temperature and $\sum S$ were positively and significantly correlated $(\mathrm{r}=0.42, \mathrm{p}<0.05, \mathrm{df}=38)$. As $\mathrm{CH}_{4}$ was estimated based on the temperature, it showed exactly the same trends and is therefore not considered in further detail here. A non-parametric Kruskal-Wallis test confirmed significant variations in both temperature $(\mathrm{H}=576.55, \mathrm{p}<0.001, \mathrm{df}=5)$ and $\sum \mathrm{S}$ values $(\mathrm{H}=26.16, \mathrm{p}=0.001, \mathrm{df}=5)$ on the different faunal assemblages (Fig. 4).

The temperature values measured in Assemblage 1 showed the largest variations, when compared to the other mussel-based assemblage values. The mussel clumps of Assemblage 2a had a higher mean temperature than Assemblages 1 and 2b. Assemblage 4b had a 230 significantly higher temperature than Assemblage $4 a(p<0.001)$, a trend opposite to that observed between Assemblages 2a and 2b (Fig. 4a). Post-hoc testing revealed that 
differences in the temperature values between all the assemblages were significant $(\mathrm{p}<0.001)$ except between Assemblages 1 and $4 \mathrm{~b}(\mathrm{p}>0.05)$.

For the $\sum \mathrm{S}$ values, the differences between the different assemblages were less pronounced (Table 2, Fig. 4b), with concentrations ranging from 0.4 to $28 \mu \mathrm{M}$. Assemblage 3 exhibited the broadest range and the highest values. Assemblages $4 \mathrm{a}$ and $4 \mathrm{~b}$ exhibited higher $\sum \mathrm{S}$ values than the other mussel assemblages, while $\sum \mathrm{S}$ concentrations were lower in Assemblages 1, 2a and 2b (Fig. 4b). Contrary to their temperature values, the $\sum$ S-values of Assemblages 4a and $4 \mathrm{~b}$ were closer to those of Assemblage 3 than the other assemblages. The differences between Assemblages 1 and 2 were not significant for $\sum S(p>0.1)$. Significant differences are found between Assemblage $2 \mathrm{~b}$ and Assemblage $3(\mathrm{p}<0.05)$, between Assemblage 4a and Assemblages 1, as well as between Assemblages $4 a$ and $2 \mathrm{~b}(\mathrm{p}<0.05)$.

\section{Habitat characteristics}

When plotting the temperature vs. the concentrations of $\Sigma S$ measured within the different faunal assemblages, all the points are limited to quite a narrow range (Fig. 5) with a strong curvature in the smoothed dilution curve. Assemblage 3 clearly had the broadest temperature range and the highest concentrations of $\sum \mathrm{S}$. The microhabitats of the larger- and mediumsized mussels (Assemblages 1 and 2) were consistent. The $\mathrm{T}^{\circ} \mathrm{C}-\sum \mathrm{S}$ values measured in the larger-sized mussel beds of Assemblage 1 were positioned on a gentle slope (slope of curve=1.92). The mussel clumps with microbial mats (Assemblage 2b) had slightly lower $\Sigma \mathrm{S}$ values than the mussel clumps without microbial cover (Assemblage 2a), which also had a higher temperature than the former (Table 2, respective slopes are 1.67 and 3.02). The plotting of Assemblages 4a and 4b above the observed dilution curve (Fig. 5), highlights their elevated levels of $\Sigma \mathrm{S}$ compared with the temperature and the ratios of the other mussel-based assemblages (Table 2). Both had steep slopes in the $\mathrm{T}^{\circ} \mathrm{C}-\sum \mathrm{S}$ curve, for which the slope of their curves are 7.19 for Assemblage 4a and -13.19 for Assemblage 4b. Even so, the assemblage with microbial cover (4b) had lower $\sum$ S-values for higher temperatures than the same assemblage without visible microbial mats (Assemblage 4a).

\section{Fauna-habitat relations}

263 Ordinations with Hellinger-transformed species abundance data were used to unravel patterns 264 between species and assemblages (Principal Component Analysis (PCA), Fig. 6). A total 
variation of $92.4 \%$ was explained by the first two axes, of which the first axis accounted for 79.6\% (Fig. 6). Assemblages for which the distance separating them equals zero are considered similar. Therefore Assemblages 2a and 4a as well as Assemblages 1 and 2b were considered more similar regarding their species composition and abundance, while Assemblage 3 was more distinct from the others. The positioning of Assemblages 1, 2b and 3 was largely influenced by the abundance of Mirocaris fortunata in these assemblages. Assemblages 2a and 4a were considered similar because of the shared abundance of Lepetodrilus atlanticus and Protolira valvatoides gastropods. In addition to Bathymodiolus azoricus, the mussel-based assemblages (i.e. Assemblages 1, 2a, 2b and 4a) are characterised by the presence of different polychaete taxa.

When plotting histograms of the percentage of temperature measurements in categories separated by $0.5^{\circ} \mathrm{C}$, preference for a certain temperature regime was revealed for each assemblage (Fig. 7). All mussel-based assemblages grouped together in the colder temperature array $\left(4.44^{\circ} \mathrm{C}-6.14^{\circ} \mathrm{C}\right)$, while the shrimp assemblage had the broadest range in the warmer temperatures $\left(5.18^{\circ} \mathrm{C}-9.54^{\circ} \mathrm{C}\right)$. Two temperature niches were thus revealed. In addition, a significant positive correlation was observed between the mussel size and the temperature, where the increasing mussel size corresponded to increasing temperature $\left(\mathrm{R}^{2}=0.9986, \mathrm{p}<0.01\right.$, $\mathrm{df}=27$, Fig. 7). The larger-sized mussels of Assemblage 1 had the broadest range and the highest temperature, overlapping in temperature with the beginning of the shrimp-niche. Assemblage 2a is present in the $5-6^{\circ} \mathrm{C}$ range, while Assemblage $2 \mathrm{~b}$ spanned $4-5^{\circ} \mathrm{C}$, with a higher numbers of measurements between $4.5-5^{\circ} \mathrm{C}$. Assemblage 4 a had $100 \%$ of its measurements in the range $4.5^{\circ} \mathrm{C}-5^{\circ} \mathrm{C}$, while Assemblage $4 \mathrm{~b}$ featured higher temperatures.

\section{Discussion}

\section{Physico-chemical characteristics of assemblages}

292 Widest temperature and $\Sigma S$ ranges are found in the shrimp assemblage (Assemblage 3). The second largest temperature variations are encountered in the larger-sized mussel-beds of Assemblage 1. In the remaining assemblages, composed of medium and smaller-sized mytilids, a narrower range of temperature values is observed. The $\sum S$ measurements show different results, as wider ranges are encountered in the assemblages featuring small dispersed 
mussels on predominating bare surface (Assemblages 4). In other words, the $\sum S$ concentration of Assemblage 4a, and to a lesser extent Assemblage 4b, is higher than for other mussel-based assemblages with similar or higher temperatures, e.g. Assemblages 1 and 2b. This might result from the preponderance of bare surface and consequently a lower biological uptake by the small and dispersed animals. In fact, what we measure in the vicinity of the fauna results from what is supplied by the fluids and what disappears through precipitation and organism consumption.

Assemblage 3 inhabits localities with relatively high temperatures and associated high levels of $\sum \mathrm{S}$, which should be a common feature since these abiotic factors are positively correlated. Within vent mussel beds, however, temperature and chemistry do not necessarily conform to a conservative mixing model (Le Bris et al., 2006). The concave curvature we observe in the $\mathrm{T}^{\circ} \mathrm{C}-\sum \mathrm{S}$ plot is indicative for sulfide removal (Johnson et al., 1988b). This suggests that mussels may influence chemistry by removing $\mathrm{H}_{2} \mathrm{~S}$ through their endosymbionts (Fisher, 1990), altering the already existing gradients (Johnson et al., 1988b). The presence of the animals might also result in a higher degree of precipitation of chemicals (Sarradin et al., 1999). When plotting temperature vs. $\sum S$, the medium to larger-sized mussel beds (Assemblages 1, 2a and 2b) tend to group together. The $\sum$ S-values in Assemblage 1, associated with a broad T-range, are positioned on a gentle slope, which can imply that larger mussels consume more $\mathrm{H}_{2} \mathrm{~S}$. Assemblage $2 \mathrm{~b}$ has a gentler $\mathrm{T}-\mathrm{S}$ s slope than Assemblage 2a suggesting that mussel-assemblages with, in addition to their endosymbionts, a microbial cover on their shells also have a higher $\mathrm{H}_{2} \mathrm{~S}$ consumption (Le Bris et al., 2006). Assemblages with the predominance of bare surface (Assemblages $4 \mathrm{a}$ and $4 \mathrm{~b}$ ) tend to cluster above the dilution curve, approaching a proximal-plume model at Eiffel Tower (Sarradin et al., in prep., Fig. 5). Nonetheless, the measurements of the majority of mussel-based assemblages are coherent with the mussel microhabitat measurements from 2006 (De Busserolles et al., 2009; Vuillemin et al., 2009), except for Assemblage 4a.

At Eiffel Tower, shrimps (Assemblage 3) live closest to the fluid exits, followed by larger sized-mussels (Assemblage 1) and with further increasing distance, by the smaller-sized mussels in the mussel-clumps of Assemblage 2 (Comtet \& Desbruyères, 1998; Sarradin et al., 1999; Cuvelier et al., 2009). The distance to the fluid exits increases even more for the small 
mussel size with increasing distance from the fluid exit observed at Eiffel Tower was suspected to correspond to a decline in temperature (Comtet \& Desbruyères, 1998; Sarradin et al., 1999; Desbruyères et al., 2001), which was confirmed here, as a significant positive correlation is observed between mussel size and temperature. Overall, we discern two temperature niches, distinguishing the mussel-based assemblages from the shrimp assemblage. Despite the overlap in temperature niche and range of the larger-sized mussels of Assemblage 1 and the shrimps, mussels generally thrive in the colder regions as opposed to the shrimps that prefer warmer localities.

Environmental fluctuations provide opportunities for niche partitioning. As the different mussel-assemblages appear to occupy the same temperature niche, the individual assemblages do show differences in overlap among each other. Assemblages with microbial cover and the ones without are significantly different from each other regarding their temperature values (see Assemblages 2a-2b and 4a-4b). We could hypothesise that the microbial cover has an effect on the local environment or on the mussels either by increasing sulfide consumption or by supplying energy from chemosynthesis to the mussels. However, until now, no physiological (no significant differences in lipids, carbohydrates or total proteins) nor toxicological (no significant differences in metals and metallothioneins) differences were found between mussels with or without microbial cover (Martins et al., 2009). Additionally, the differences observed are not consistent between the sub-forms of assemblages, as Assemblage 2a has higher temperature values than Assemblage 2b while it is the other way around for Assemblages 4a and 4b. Overall, Assemblage 2a has a relative high mean temperature compared with the other mussel-based assemblages, as do Assemblages 4a and $4 \mathrm{~b}$, although their maximum temperature is lower than that of Assemblages 1 and 3 . There are two possible explanations for this feature; the first is the ability of the mussels to divert the flow horizontally, which allows them to expand the spatially limited, redox-transition zone (Johnson et al., 1988a; 1994). As a consequence, higher temperatures tend to occur at the edges of the mussel clumps (Johnson et al., 1988b). The second explanation is that during sampling the temperature sensor touched the (underlying) rocky, thereby measuring conductive heatflow from subsurface circulation of hot hydrothermal fluids.

Previous studies have hypothesised the existence of different physico-chemical microhabitats at the Eiffel Tower edifice (Sarradin et al., 1999; Cuvelier et al., 2009), supposedly dividing it 
sulfide) environment, with the shrimps and larger-sized mussels inhabiting the harshest one, and the smaller-sized mussels occupying the other one. Based on the data acquired for this study, these two microhabitats are characterised by variability rather than harshness, although they also feature the highest and lower maximum temperatures. All values of temperature, $\Sigma S$ and $\mathrm{CH}_{4}$ presented in this study are in concordance with previously published values for this edifice and MAR mussel beds (Sarradin et al., 1999; 2009).

\section{Faunal characteristics}

Mirocaris fortunata, the most abundant shrimp at Eiffel Tower, can tolerate warm fluids at the MAR vents $\left(36^{\circ} \mathrm{C}\right.$; Shillito et al., 2006), which explains their presence in the warmer regions. This shrimp species is an opportunist and feeds on a great variety of food items, such as microbial mats and tissues of other invertebrates (Gebruk et al., 2000; Colaço et al., 2002). They can be found in several mussel-based assemblages, mostly where there is a microbial cover present as well as on bare substrata, with no mussels. In addition, the less gregarious Chorocaris chacei and the more solitary Alvinocaris markensis also occur at Lucky Strike and Eiffel Tower (Desbruyères et al., 2006). Of the latter two species, there were no individuals present in our samples, even though video imagery of Assemblage 3 showed that $M$. fortunata co-occur with low abundances of C. chacei (Cuvelier et al., 2009). The absence of certain 'expected' species can be explained by the 'patchy' nature of the hydrothermal vent edifices along with our limited number of samples $(n=5)$.

Bathymodiolus azoricus is the dominant species of the Eiffel Tower edifice and for the entire Lucky Strike vent field, representing a climax-community. Bathymodiolus can be regarded as an engineering species, offering secondary surfaces and interstitial microhabitats for other organisms to occupy (Van Dover \& Trask, 2000). Structurally complex localities may allow the coexistence of many more species through competition-induced habitat specialization or through moderation of predation (Menge \& Sutherland, 1976). In this way, mytilids promote biodiversity by enhancing habitat complexity and altering the local physico-chemical habitat. Gastropods (mainly Protolira valvatoides, Lepetodrilus atlanticus and Pseudorimula midatlantica) and even new mytilid recruits of Bathymodiolinae can be found on top of the mussel shells, although gastropod presence is limited to the smaller-sized mussel-based assemblages without microbial cover (2a and 4a). The microbial presence appears to exclude gastropod fauna. These gastropods probably feed on the detrital layer and biofilms covering 
difficulties for attachment and movement of the gastropods. Larger-sized mussels could filter

399 a larger amount of gastropod larvae out of the water column, inhibiting settlement. Presence and abundance of polychaetes differed from that of the gastropods. The gastropods are exclusively present in the smaller-sized mussel assemblages without microbial cover. While several polychaete species are clearly associated with the mussels, such as Amathys lutzi and Branchinotogluma mesatlantica, which live in the interstitial spaces between the mussels and are present in all mussel-based assemblages. At Eiffel Tower, polynoid polychaetes are often visible on the mussel beds and microbial mats. One of them, the commensal polychaete Branchipolynoe seepensis lives in the mantle cavity of the mussels. The abundance of Branchipolynoe is lowest in the very small mussel-based assemblages (Assemblages 4a and 4b), which is also visible in the PCA-plot.

\section{Sample/assemblage similarity}

411 The highest similarity in faunal abundances and species composition is observed between 412 Assemblages 2a and 4a, which could be a different stage of the same assemblage. It is 413 Assemblage 3 that stands out, while Assemblages 1 and $2 \mathrm{~b}$ are more similar to one another as 414 well. Due to this high faunal similarity between the latter two, there is no clear boundary 415 between the assemblages able to withstand the highest environmental fluctuations (1 and 3) 416 and those tolerating smaller environmental variable ranges ( $2 a, 2 b$ and $4 a$ ). This feature of 417 species crossing the borders delineated by the variability in microhabitats is due to the 418 existence of two temperature niches wherein the mussel-based assemblages group together 419 under a colder temperature regime $\left(4.44^{\circ} \mathrm{C}-6.14^{\circ} \mathrm{C}\right)$.

\section{Richness and expected number of species}

422 The least diverse assemblage is the shrimp assemblage (Assemblage 3) and is also found 423 closest to the fluid exits (Cuvelier et al., 2009). This corresponds to the most variable 424 environment and could be considered the most stressful. At first sight there seems to be an 425 increase in taxonomic richness with distance from a fluid exit with Assemblage 4a, situated the 426 furthest away from a fluid exit, showed the highest richness. The expected number of species 427 corroborated this, although differences were less pronounced. This increasing distance is 428 hypothesised to correspond to a decrease in variability/stress as well. This is confirmed as there 429 is a significant negative relation between $\operatorname{Es}(100)$ and the standard deviations of the 430 temperature, which are a measure for the variability. Richness is likely to be subject to the 431 surface area sampled, while rarefaction tends to mitigate this artefact. However, caution should 
432 be taken as our observations are based on a small number of samples and that the evaluation of 433 species richness is largely dependant on this number of samples and the surface area sampled 434 (Gauthier et al., 2010).

\section{Summary}

437 At Eiffel Tower, variability rather than differences in mean conditions distinguishes two 438 microhabitats, in which temperature is proposed as being a more limiting factor than $\sum \mathrm{S}$. The 439 first and most variable microhabitat (broadest ranges in temperature values), also features the 440 highest maximum temperatures, is inhabited by the alvinocaridid shrimps (Assemblage 3) and 441 the larger-sized mussels (Assemblage 1). The second, more stable habitat, is inhabited by the 442 smaller-sized mussels in clumps (without and with microbial cover respectively Assemblages $4432 \mathrm{a}$ and $2 \mathrm{~b}$ ) and dispersed small mussels (without and with microbial cover respectively 444 Assemblages 4a and 4b).

445 Hydrothermal vent animals such as mussels modify the local environment as we measure and 446 perceive it. Larger mussels (present in Assemblages 1 and 2) appear to consume more $\sum S$ than 447 smaller-sized individuals ( $\sim \mathrm{cm}$, Assemblage 4). A higher $\sum \mathrm{S}$ consumption can also be 448 postulated for the mussel clumps that have an additional microbial cover on their shells 449 (Assemblage 2a). The mussel size was also shown to be positively correlated to the 450 temperature and negatively with the associated macrofauna richness. There is no evidence of 451 the microbial cover being associated to specific environmental conditions or of its influence on 452 the local chemistry, though its presence excluded gastropod fauna. The distinction between the 453 two microhabitats is less clear when looking at species abundances. Despite several marked 454 differences in presence and abundance of species between the visibly different faunal 455 assemblages, there are species (e.g. Mirocaris fortunata and several polychaete species) that 456 cross the boundaries delineated by the microhabitats. This was explained by the existence of 457 two temperature niches: one for the mussel-based assemblages in the colder temperature areas 458 and the other for the shrimps in the warmer regions, with an overlap in temperature-niche 459 between the larger-sized mussels and the shrimps. A more thorough sampling at Eiffel Tower, 460 both biologically (including replicates, meiofauna assessment and different sampling 461 efficiency) as chemically (consideration of other electron donors, time-series measurements) is 462 needed to validate our findings or highlight possible other factors at play, which we were 463 unable to assess at this point. Additional sampling of similar faunal assemblages originating 
464

465

466

467

468

469

470

471

472

473

474

475

476

477

478

479

480

481

482

483

484

485

486

487

488

489

490

491

492

493

494

495

496

497

498

499

500

from other edifices within Lucky Strike would be the next step in testing the consistencies of the differences in faunal assemblages at this vent field.

\section{$\underline{\text { Acknowledgments }}$}

We would like to thank Javier Escartin, chief scientist of the MoMAR08 cruise, for his collaboration and attribution of diving time. We would like to extend our thanks to captain Michel Houmard of N.O. l'Atalante, and his crew for their cooperation, indispensable assistance and availability. We would also like to express our gratitude to the pilots of ROV Victor 6000 for their patience, expertise and willingness and to Patrick Briand and Marie Morineaux for their valuable and much appreciated help in preparing the cruise. The $\mathrm{PhD}$ project (D. Cuvelier) has been carried out in the framework of the MarBEF Network of Excellence 'Marine Biodiversity and Ecosystem Functioning' which is funded by the Sustainable Development, Global Change and Ecosystems Programme of the European Community's Sixth Framework Programme (contract no. GOCE-CT-2003-505446). D. Cuvelier also benefited from an extra year of funding from FCT (Fundação de Ciência e Tecnologia, grant SFRH/BD/47301/2008). This work was also partly funded by the EU projects ESONET contract \#0366851 and HERMIONE, contract \# 226354. This manuscript also benefited from the comments and suggestions of three anonymous reviewers.

\section{$\underline{\text { References }}$}

Bates A. E., Tunnicliffe V., Lee R. W. (2005). Role of thermal conditions in habitat selection by hydrothermal vent gastropods. Marine Ecology-Progress Series, 305, 1-15.

Charlou J.L., Dental J.P., Douville E., Jean-Baptiste P., Radford-Knoery J., Fouquet Y., Dapoigny A., Stievenard M., (2000). Compared geochemical signatures and the evolution of

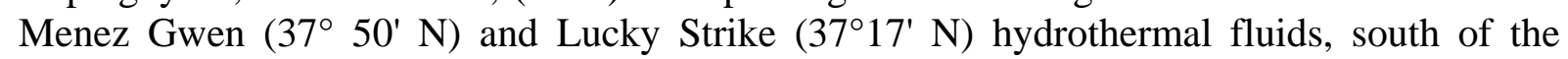
Azores Triple Junction on the Mid-Atlantic Ridge. Chemical Geology, 171, 49-75

Chevaldonné P., Desbruyères D., Lehaitre M. (1991). Time-series of temperature from 3 deep-sea hydrothermal vent sites. Deep-Sea Research Part a-Oceanographic Research Papers, 38, 1417-1430.

Colaço A., Dehairs F., Desbruyères D. (2002). Nutritional relations of deep-sea hydrothermal fields at the Mid-Atlantic Ridge: a stable isotope approach. Deep-Sea Research Part IOceanographic Research Papers, 49, 395-412.

Comtet T., Desbruyères D. (1998). Population structure and recruitment in mytilids bivalves from the Lucky Strike and Menez Gwen hydrothermal vent fields $\left(37^{\circ} 17^{\prime} \mathrm{N}\right.$ and $37^{\circ} 50^{\prime} \mathrm{N}$ on 
502 Cuvelier D., Sarrazin J., Colaço A., Copley J., Desbruyères D., Glover A.G., Tyler P., Serrão 503 Santos R. (2009). Distribution and spatial variation of Atlantic hydrothermal faunal 504 assemblages revealed by high-resolution video image analysis. Deep Sea Research IOceanographic Research Papers, 56, 2026-2040.

506

507

508

509

510

511

512

513

514

515

516

517

518

519

520

521

522

523

524

525

526

527

528

529

530

531

532

533

534

535

536

537

538

539

540

541

542

543

De Busserolles F., Sarrazin J., Gauthier O., Gélinas Y., Fabri M.C., Sarradin P.M., Desbruyères D. (2009). Are spatial variations in the diets of hydrothermal fauna linked to local environmental conditions? Deep Sea Research II- Topical Studies in Oceanography, 56, 1649-1664.

Desbruyères D., Almeida A., Biscoito M., Comtet T., Khripounoff A., Le Bris N., Sarradin P. M., Segonzac M. (2000). A review of the distribution of hydrothermal vent communities along the northern Mid-Atlantic Ridge: dispersal vs. environmental controls. Hydrobiologia, 440, 201-216.

Desbruyères D., Biscoito M., Caprais J. C., Colaço A., Comtet T., Crassous P., Fouquet Y., Khripounoff A., Le Bris N., Olu K., Riso R., Sarradin P. M., Segonzac M., Vangriesheim A. (2001). Variations in deep-sea hydrothermal vent communities on the Mid-Atlantic Ridge near the Azores plateau. Deep-Sea Research Part I-Oceanographic Research Papers, 48, 1325-1346.

Desbruyères D., Segonzac M., Bright M. (Eds) (2006). Handbook of deep-sea hydrothermal vent fauna. Second completely revised edition. Denisia, 18. Biologiezentrum der Oberösterreichischen Landesmuseen. Linz, Austria: 544 pp.

Dreyer J. C., Knick K. E., Flickinger W. B., Van Dover C. L. (2005). Development of macrofaunal community structure in mussel beds on the northern East Pacific Rise. Marine Ecology Progress Series, 302, 121-134.

Fisher C. R., Childress J. J., Arp A. J., Brooks J. M., Distel D., Favuzzi J. A., Felbeck H., Hessler R., Johnson K. S., Kennicutt M. C., Macko S. A., Newton A., Powell M. A., Somero G. N., Soto T. (1988). Microhabitat variation in the hydrothermal vent mussel, Bathymodiolus thermophilus, at the Rose Garden vent on the Galapagos Rift. Deep-Sea Research Part aOceanographic Research Papers, 35, 1769-1791.

Fisher C. R., (1990). Chemoautotrophic and methanotrophic symbioses in marine invertebrates. Reviews in Aquatic Science, 2, 399-436.

Fouquet Y., Eissen J. P., Ondreas H., Barriga F., Batiza R., Danyushevsky L. (1998). Extensive volcaniclastic deposits at the Mid-Atlantic Ridge axis: results of deep-water basaltic explosive volcanic activity? Terra Nova, 10, 280-286.

Gauthier O., Sarrazin J., Desbruyères D. (2010). Measure and mis-measure of species diversity in deep-sea chemosynthetic communities. Marine Ecology Progress Series, 402, 285-302.

Gebruk A. V., Southward E. C., Kennedy H., Southward A. J. (2000). Food sources, behaviour, and distribution of hydrothermal vent shrimps at the Mid-Atlantic Ridge. Journal of the Marine Biological Association of the United Kingdom, 80, 485-499. 
Govenar B., Le Bris N., Gollner S., Glanville J., Aperghis A. B., Hourdez S., Fisher C. R. (2005). Epifaunal community structure associated with Riftia pachyptila aggregations in chemically different hydrothermal vent habitats. Marine Ecology-Progress Series, 305, 67-77

Henry M. S., Childress J. J., Figueroa D. (2008). Metabolic rates and thermal tolerances of chemoautotrophic symbioses from Lau Basin hydrothermal vents and their implications for species distributions. Deep-Sea Research Part I-Oceanographic Research Papers,55, 679695

Jannasch H.W. (1985). The chemosynthetic support of life and the microbial diversity at deep-sea hydrothermal vents. Proceedings of the Royal Society of London, Series B, Biological sciences, 225, 277-297

Johnson K. S., Childress J. J., Beehler C. L. (1988a). Short-term temperature variability in the Rose Garden hydrothermal vent field - an unstable deep-sea environment. Deep-Sea Research Part a-Oceanographic Research Papers, 35, 1711-1721

Johnson K. S., Childress J. J., Hessler R. R., Sakamoto-Arnold C. M., Beehler C. L. (1988b). Chemical and biological interactions in the Rose Garden hydrothermal vent field, Galapagos Spreading Center. Deep-Sea Research Part a-Oceanographic Research Papers, 35, 17231744.

Johnson K. S., Childress J. J., Beehler C. L., Sakamoto C. M. (1994). Biogeochemistry of hydrothermal vent mussel communities - the deep-sea analogue to the intertidal zone. DeepSea Research Part I-Oceanographic Research Papers, 41, 993-1011.

Langmuir C., Humphris S., Fornari D., Van Dover C., Von Damm K., Tivey M. K., Colodner D., Charlou J. L., Desonie D., Wilson C., Fouquet Y., Klinkhammer G., Bougault H. (1997). Hydrothermal vents near a mantle hot spot: the Lucky Strike vent field at 37 degrees $\mathrm{N}$ on the Mid-Atlantic Ridge. Earth and Planetary Science Letters, 148, 69-91.

Le Bris N., Govenar B., Le Gall C., Fisher C.R. (2006). Variability of physico-chemical conditions in 9850VN EPR diffuse flow vent habitats. Marine Chemistry, 98, 167-182

Legendre P., Gallagher E.G. (2001). Ecologically meaningful transformations for ordination of species data. Oecologia, 129, 271-280

Luther G. W., Rozan T. F., Taillefert M., Nuzzio D. B., Di Meo C., Shank T. M., Lutz R. A., Cary S. C. (2001). Chemical speciation drives hydrothermal vent ecology. Nature, 410, 813816.

Lutz R. A., Shank T. M., Luther G. W., Vetriani C., Tolstoy M., Nuzzio D. B., Moore T. S., Waldhauser F., Crespo-Medina M., Chatziefthimiou A. D., Annis E. R., Reed A. J. (2008). Interrelationships between vent fluid chemistry, temperature, seismic activity, and biological community structure at a mussel-dominated, deep-sea hydrothermal vent along the East Pacific Rise. Journal of Shellfish Research, 27, 177-190.

Martins I., Colaco A., Santos R. S., Lesongeur F., Godfroy A., Sarradin P. M., Cosson R. P. (2009). Relationship between the occurrence of filamentous bacteria on Bathymodiolus azoricus shell and the physiological and toxicological status of the vent mussel. Journal of Experimental Marine Biology and Ecology, 376, 1-6. 
Matabos M., Le Bris N., Pendlebury S., Thiébaut E. (2008). Role of physico-chemical environment on gastropod assemblages at hydrothermal vents on the East Pacific Rise (13 N/EPR). Journal of the Marine Biological Association of the United Kingdom, 88, 9951008

Menge B.A., Sutherland J.P. (1976). Species diversity gradients: synthesis of the role of predation, competition and temporal heterogeneity. The American Naturalist, 110, 351-369

Mills S. W., Mullineaux L. S., Tyler P. A. (2007). Habitat associations in gastropod species at East Pacific Rise hydrothermal vents (9 degrees 50 ' N). Biological Bulletin, 212, 185-194.

Oksanen J., Kindt R., Legendre P., O’Hara B., Simpson G.L., Solymos P., Stevens M.H.M., Wagner H. (2008). vegan: Community Ecology Package. $R$ package version 1.15-0. http://cran.r-project.org/S, http://vegan.r-forge.r-project.org/.

Ondréas H., Cannat M., Fouquet Y., Normand A., Sarradin P. M., Sarrazin J. (2009). Recent volcanic events and the distribution of hydrothermal venting at the Lucky Strike hydrothermal field, Mid-Atlantic Ridge. Geochemistry Geophysics Geosystems, 10 (2).

Podowski E.L., Moore T.S., Zelnio K.A., Luther III G.W., Fisher C.R. (2009). Distribution of diffuse flow megafauna in two sites on the Eastern lau Spreading Center, Tonga. Deep Sea Research I-Oceanographic Research Papers, 56, 2041-2056

Sarradin P. M., Caprais J. C., Briand P., Gaill F., Shillito B., Desbruyères D. (1998). Chemical and thermal description of the environment of the Genesis hydrothermal vent community (13º N, EPR). Cahiers de Biologie Marine, 39, 159-167.

Sarradin P. M., Caprais J. C., Riso R., Kerouel R., Aminot A. (1999). Chemical environment of the hydrothermal mussel communities in the Lucky Strike and Menez Gwen vent fields, Mid Atlantic Ridge. Cahiers de Biologie Marine, 40, 93-104.

Sarradin P.M., Waeles M., Bernagout S., Le Gall C., Sarrazin J., Riso R. (2009). Speciation of dissolved copper within an active hydrothermal edifice on the Lucky Strike vent field (MAR, $\left.37^{\circ} \mathrm{N}\right)$. Science of the Total Environment, 407, 869-878

Sarrazin J., Robigou V., Juniper S. K., Delaney J. R. (1997). Biological and geological dynamics over four years on a high-temperature sulfide structure at the Juan de Fuca Ridge Hydrothermal Observatory. Marine Ecology-Progress Series, 153, 5-24.

Sarrazin, J., Juniper, S.K. (1999). Biological Characteristics of a Hydrothermal Edifice Mosaic Community. Marine Ecology Progress Series, 185, 1-19

Sarrazin J., Juniper S. K., Massoth G., Legendre P. (1999). Physical and Chemical Factors Influencing Species Distributions on Hydrothermal Sulfide Edifices of the Juan De Fuca Ridge, Northeast Pacific. Marine Ecology Progress Series, 190, 89-112.

Sarrazin J., Walter C., Sarradin P.M., Brind'Amour A., Desbruyères D., Briand P., Fabri M.C., Van Gaever S., Vanreusel A., Bachraty C., Thiébaut E. (2006). Community structure and temperature dynamics within a mussel community on the southern East Pacific Rise. Cahiers de Biologie Marine, 47,483-490 
630 Shillito B., Le Bris N., Hourdez S., Ravaux J., Cottin D., Caprais J. C., Jollivet D., Gaill F. 631 (2006). Temperature resistance studies on the deep-sea vent shrimp Mirocatis fortunata.

632 Journal of Experimental Biology, 209, 945-955.

633 Tsurumi M., Tunnicliffe, V. (2003). Tubeworm-associated communities at hydrothermal 634 vents on the Juan De Fuca Ridge, Northeast Pacific. Deep-Sea Research Part I-

635 Oceanographic Research Papers, 50, 611-629.

636 Urcuyo I.A., Massoth G.J., Julian, D., Fisher, C.R. (2003). Habitat, growth andphysiological 637 ecology of a basaltic community of Ridgeia piscesae from the Juan de Fuca Ridge. Deep-Sea 638 Research Part I-Oceanographic Research Papers, 50, 763-780

639 Van Dover C.L., Trask J.L. (2000). Diversity at Deep-Sea Hydrothermal Vent and Intertidal 640 Mussel Beds. Marine Ecology Progress Series, 195, 169-178.

641

Vuillemin R., Le Roux D., Dorval P., Bucas K., Sudreau J.P., Hamon M., Le Gall C., 643 Sarradin P. M. (2009). CHEMINI: a new in situ CHEmical MINIaturized analyzer. Deep-Sea 644 Research Part I-Oceanographic Research Papers, 56, 1319-1399

645

646

647

648

649

650

651

652

653

654

655

656

657

658

659

660

661

662

663

664

665

666

667

668

669

670

671

672 
676 Table 1: Species densities (ind $/ \mathrm{m}^{2}$ ) and total taxonomic richness in the different faunal assemblages sampled. The undetermined species were also considered in the taxonomic

678 richness and rarefaction calculations as these were definitely different from the other

679 determined species. Highly mobile Segonzacia mesatlantica (Bythograeidae, Decapoda) crabs

680 were left out of the table. As=Assemblage

681

\begin{tabular}{|c|c|c|c|c|c|c|}
\hline \multirow[b]{2}{*}{ Group } & \multirow[b]{2}{*}{ Species } & \multicolumn{5}{|c|}{ Density (ind/m²) } \\
\hline & & As_1 & As_2a & As_2b & As_3 & As_4a \\
\hline \multicolumn{7}{|l|}{ Mollusca } \\
\hline \multicolumn{7}{|l|}{ Gastropoda } \\
\hline \multirow[t]{2}{*}{ Lepetodrilidae } & Lepetodrilus atlanticus & 0 & 340 & 0 & 0 & 104 \\
\hline & Pseudorimula midatlantica & 0 & 0 & 0 & 0 & 21 \\
\hline Skeneidae & Protolira valvatoides & 0 & 1155 & 0 & 0 & 1121 \\
\hline Orbitestellidae & Lurifax vitreus & 0 & 68 & 0 & 0 & 0 \\
\hline Phenacolepadidae & Shinkailepas briandi (empty) ${ }^{\star \star}$ & 0 & 0 & 44 & 0 & 21 \\
\hline \multirow[t]{2}{*}{$\begin{array}{l}\text { Polychaeta } \\
\text { Polynoidae }\end{array}$} & Branchipolynoe seepensis & 385 & 544 & 350 & 0 & 332 \\
\hline & Branchinotogluma mesatlantica & 18 & 0 & 0 & 0 & 0 \\
\hline \multirow[t]{3}{*}{ Ampharetidae } & Amathys lutzi & 330 & 68 & 219 & 0 & 249 \\
\hline & Polychaeta indet. & 37 & 0 & 88 & 0 & 21 \\
\hline & Polynoidae indet. & 0 & 0 & 0 & 27 & 21 \\
\hline \multicolumn{7}{|l|}{$\begin{array}{l}\text { Arthropoda } \\
\text { Amphipoda }\end{array}$} \\
\hline \multirow[t]{2}{*}{ Eusiridae } & Luckia striki & 0 & 136 & 832 & 27 & 21 \\
\hline & Amphipoda indet. & 0 & 68 & 0 & 0 & 0 \\
\hline Decapoda & & & & & & \\
\hline Alvinocarididae & Mirocaris fortunata & 604 & 0 & 3065 & 3406 & 62 \\
\hline Pycnogonida & & & & & & \\
\hline$\overline{\text { Ammotheidae }}$ & Sericosura heteroscela & 0 & 0 & 0 & 0 & 123 \\
\hline Surface sampled $\mathrm{cm}^{2}$ & & 546.12 & 147.21 & 228.41 & 369.98 & 481.66 \\
\hline Taxonomic richness & & 6 & 8 & 6 & 3 & 11 \\
\hline Rarefaction Es(100) & & 5.74 & 7.75 & 5.98 & 2.56 & 8.19 \\
\hline
\end{tabular}

$682{ }^{\star *}$ Not considered in statistical analyses or diversity calculations 
Table 2: Mean values of $\mathrm{T}^{\circ} \mathrm{C}, \sum \mathrm{S}$ and $\mathrm{CH}_{4}$ and their standard deviations (stdev) measured or estimated on the different faunal assemblages. $\mathrm{T}^{\circ} \mathrm{C}$ and $\sum \mathrm{S}$ were measured in situ, $\mathrm{n}=$ number of samples, which is absent for $\mathrm{CH}_{4}$ as this factor was calculated from the in situ $\mathrm{T}^{\circ} \mathrm{C}$ values, using a $\mathrm{T}^{\circ} \mathrm{C}$ vs. $\mathrm{CH}_{4}$ regression curve. Maximum values are highlighted in grey.

701

702

\begin{tabular}{|l|cc|c|c|c|}
\cline { 2 - 6 } \multicolumn{1}{c|}{} & \multicolumn{2}{c|}{$\mathbf{T}^{\circ} \mathbf{C}$} & \multicolumn{2}{c|}{$\sum \mathrm{S}$ total $\boldsymbol{\mu M}$} & $\begin{array}{r}\mathrm{CH}_{4} \text { total } \boldsymbol{\mu} \text { 703 } \\
\text { (estimated)704 }\end{array}$ \\
\cline { 2 - 6 } \multicolumn{1}{c|}{} & $\mathbf{n}$ & Mean \pm stdev & $\mathbf{n}$ & Mean \pm stdev & Mean \pm stdey 95 \\
\hline Assemblage 1 & 120 & $5.12 \pm 0.39$ & 7 & $1.72 \pm 0.73$ & $5.59 \pm 0.75706$ \\
Assemblage 2a & 129 & $5.37 \pm 0.13$ & 6 & $1.40 \pm 0.37$ & $6.20 \pm 0.17$ \\
Assemblage 2b & 116 & $4.71 \pm 0.15$ & 7 & $0.81 \pm 0.29$ & $4.76 \pm 0.28$ \\
Assemblage 3 & 128 & $6.79 \pm 0.88$ & 8 & $9.00 \pm 11.81$ & $8.73 \pm 3.10$ \\
Assemblage 4a & 117 & $4.81 \pm 0.07$ & 6 & $4.47 \pm 0.83$ & $4.96 \pm 0.08709$ \\
Assemblage 4b & 115 & $5.01 \pm 0.10$ & 4 & $3.64 \pm 0.87$ & $5.61 \pm 0.11710$ \\
\hline
\end{tabular}




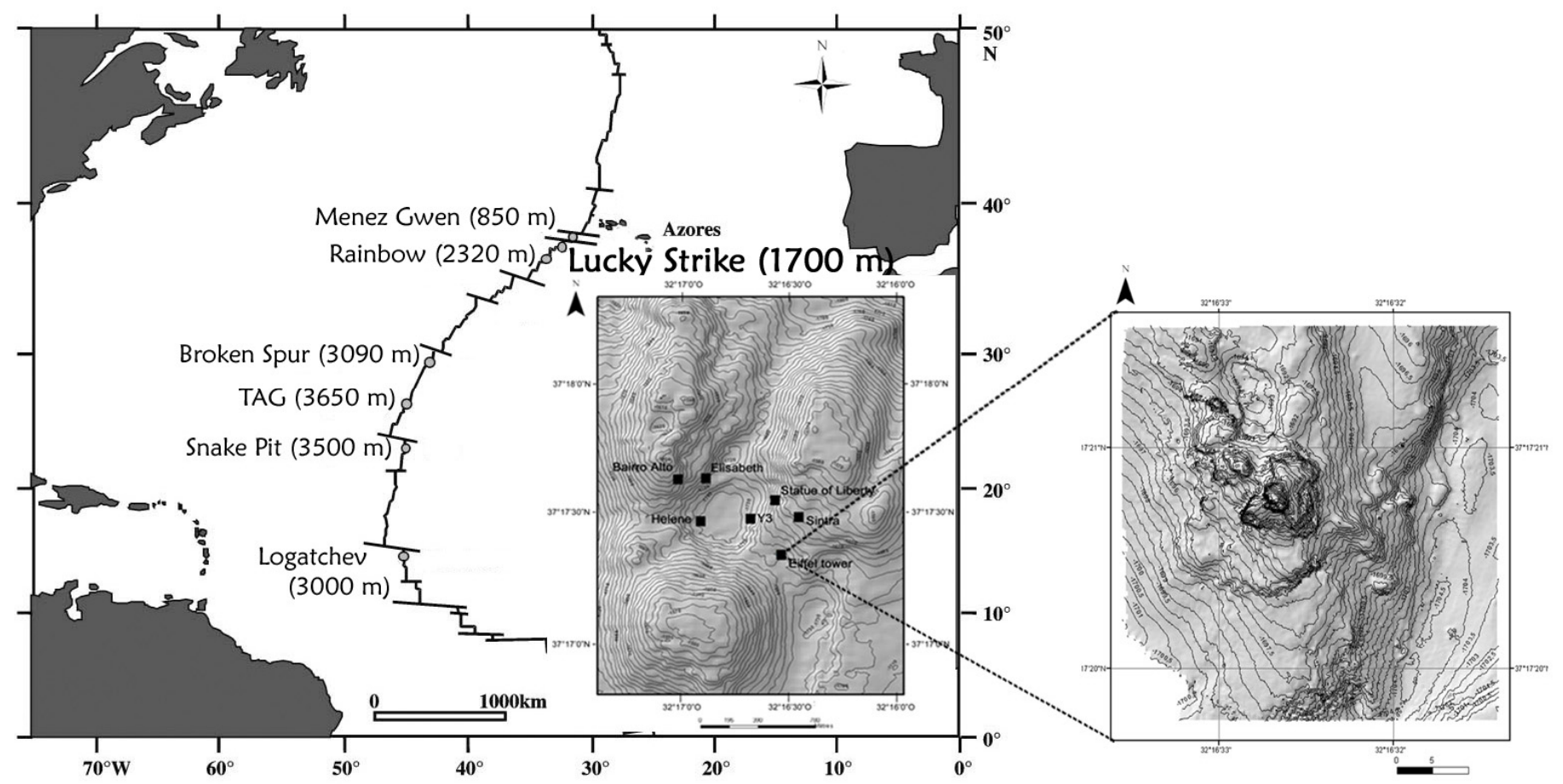

Fig. 1: Major known vent fields and their respective depths are shown along the Mid-Atlantic Ridge. The inset shows the Lucky Strike vent field with several of its most well-defined edifices. The $11 \mathrm{~m}$ high Eiffel tower is one of them, situated in the south-eastern sector of the vent field. 


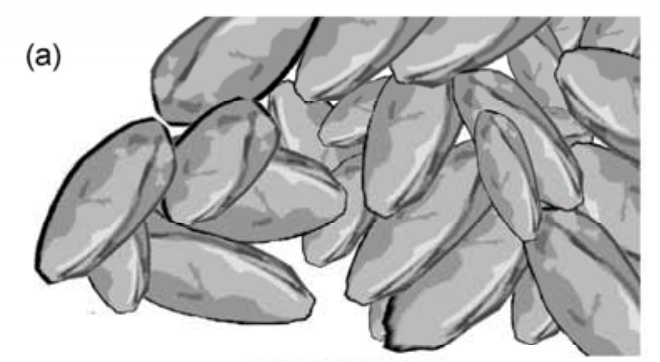

Assemblage 1

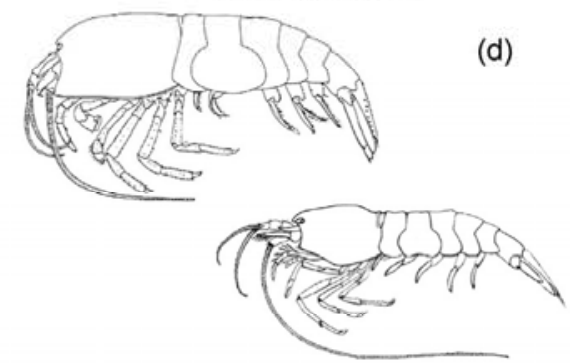

Assemblage 3

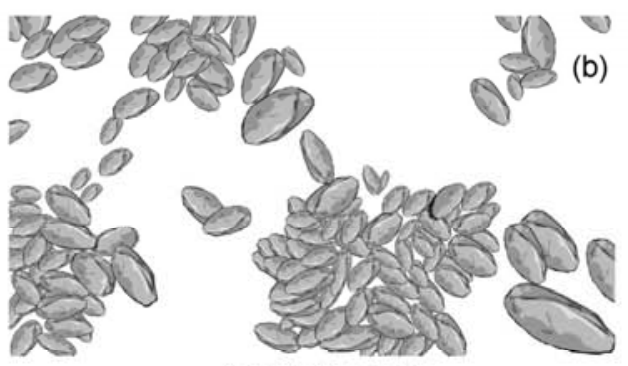

Assemblage 2a

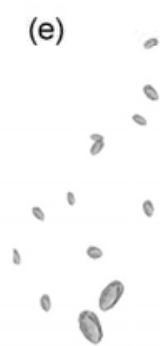

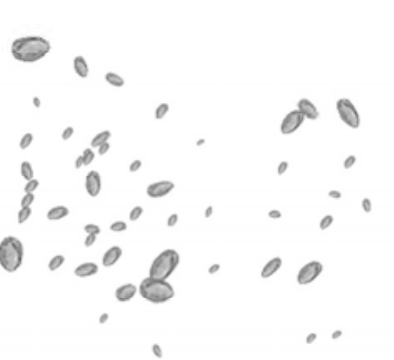

Assemblage $4 \mathrm{a}$

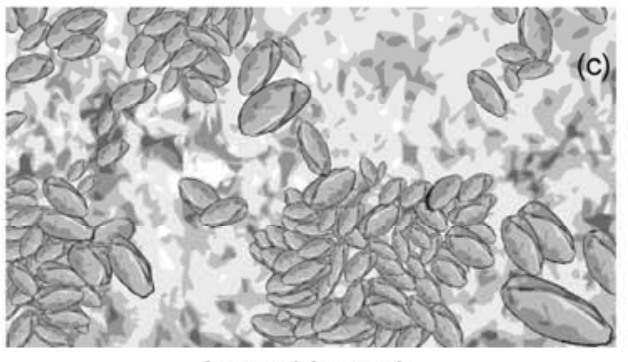

Assemblage $2 b$

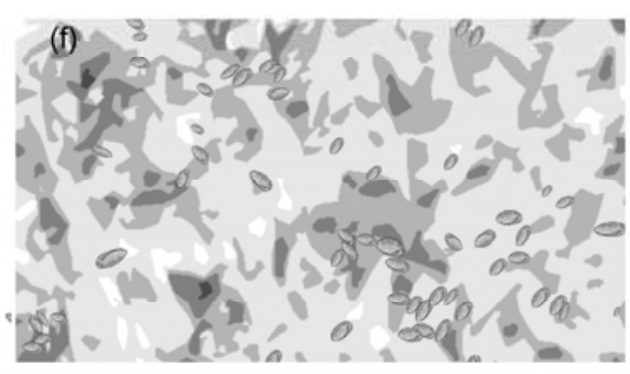

Assemblage 4b

807 Fig. 2: Assemblage identification based on imagery as described by Cuvelier et al. (2009), 808 varying in visibly dominant species (mussels and shrimp), in mussel size and in density of 809 mussel coverage. Each assemblage is represented by a sketch (a) Assemblage 1: dense 810 Bathymodiolus azoricus mussel beds of larger-sized mussels ( $\sim \mathrm{cm})$, (b) Assemblage 2a: 811 mussel clumps of smaller sized mussels $(2-5 \mathrm{~cm})$ with bare substrata in between, (c) 812 Assemblage 2b: Assemblage 2a but with a microbial cover (d) Assemblage 3: alvinocaridid 813 shrimp colonising bare surface (mostly Mirocaris fortunata, other shrimp species can be 814 recognised on imagery), (e) Assemblage 4a: scattered small mussels $(\sim 1 \mathrm{~cm})$ with prevailing 815 816 817 818 
8

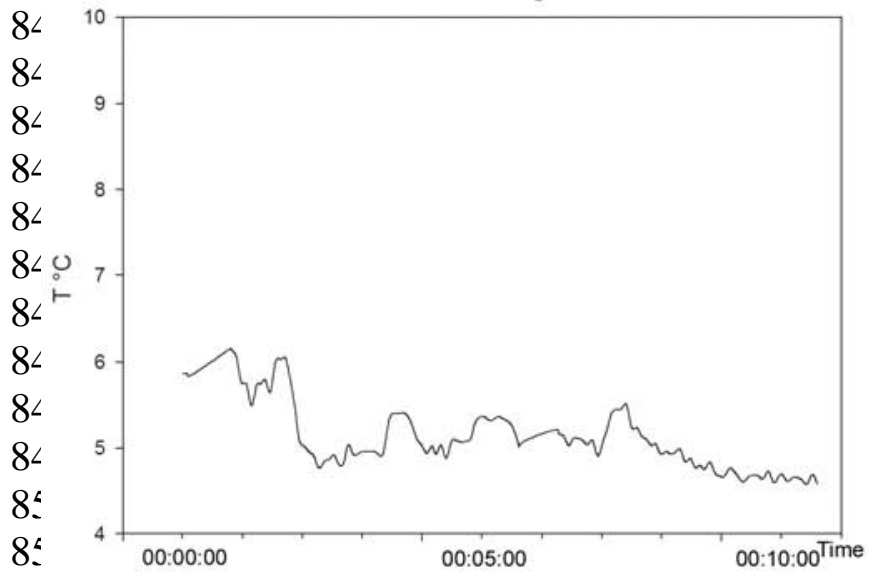

8 $\quad \mathrm{T}^{\circ} \mathrm{C}$ Assemblage 3

8 도

8 c

8 도

8 도

8 돈

8 둔

$8 \mathrm{c}$

81

$8 t$

$8 t$

$8 t$

86

860

866

867

868

869

870

871

872

873

874

875

876

877

878

879

880

881

882

883

884

885

886

887

888 sampled.
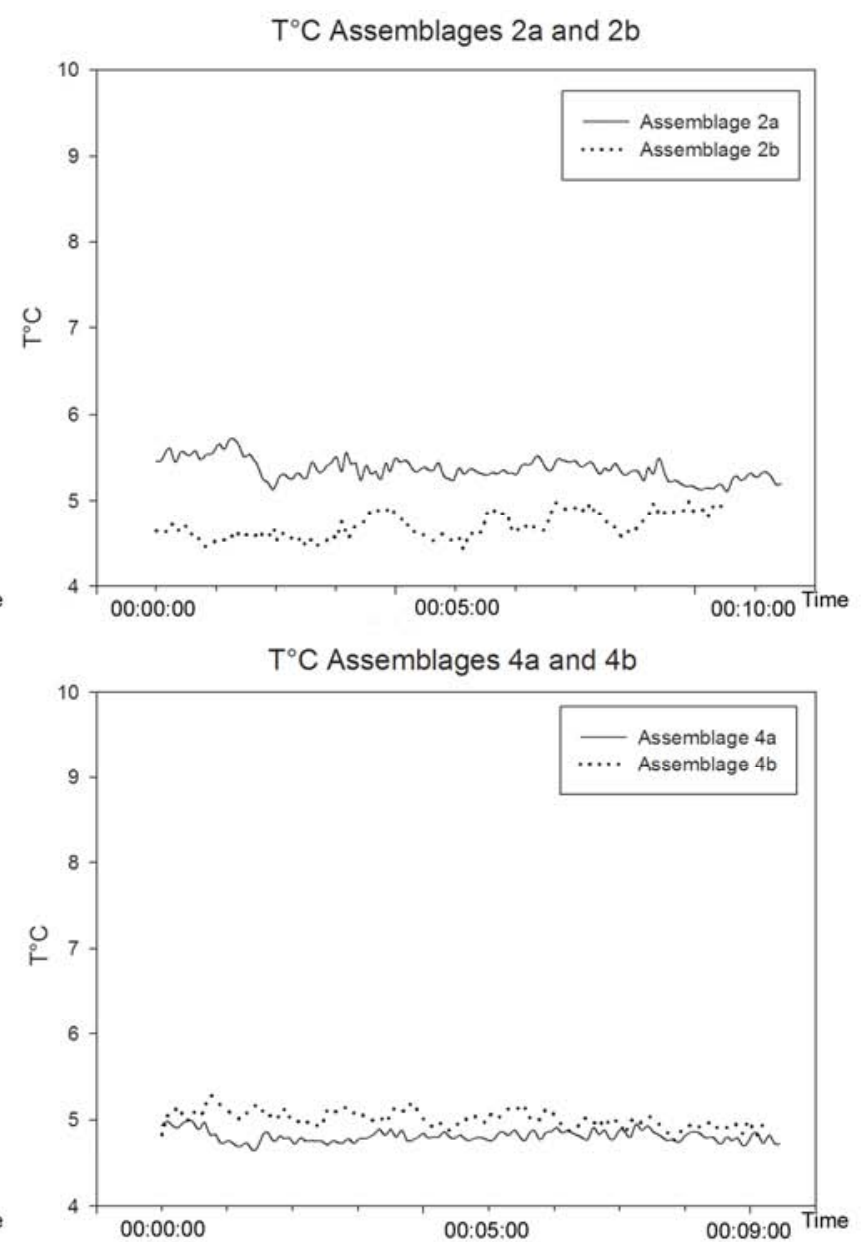

Fig. 3. Temperature fluctuations over a 10 minute time period on the different assemblages 
889
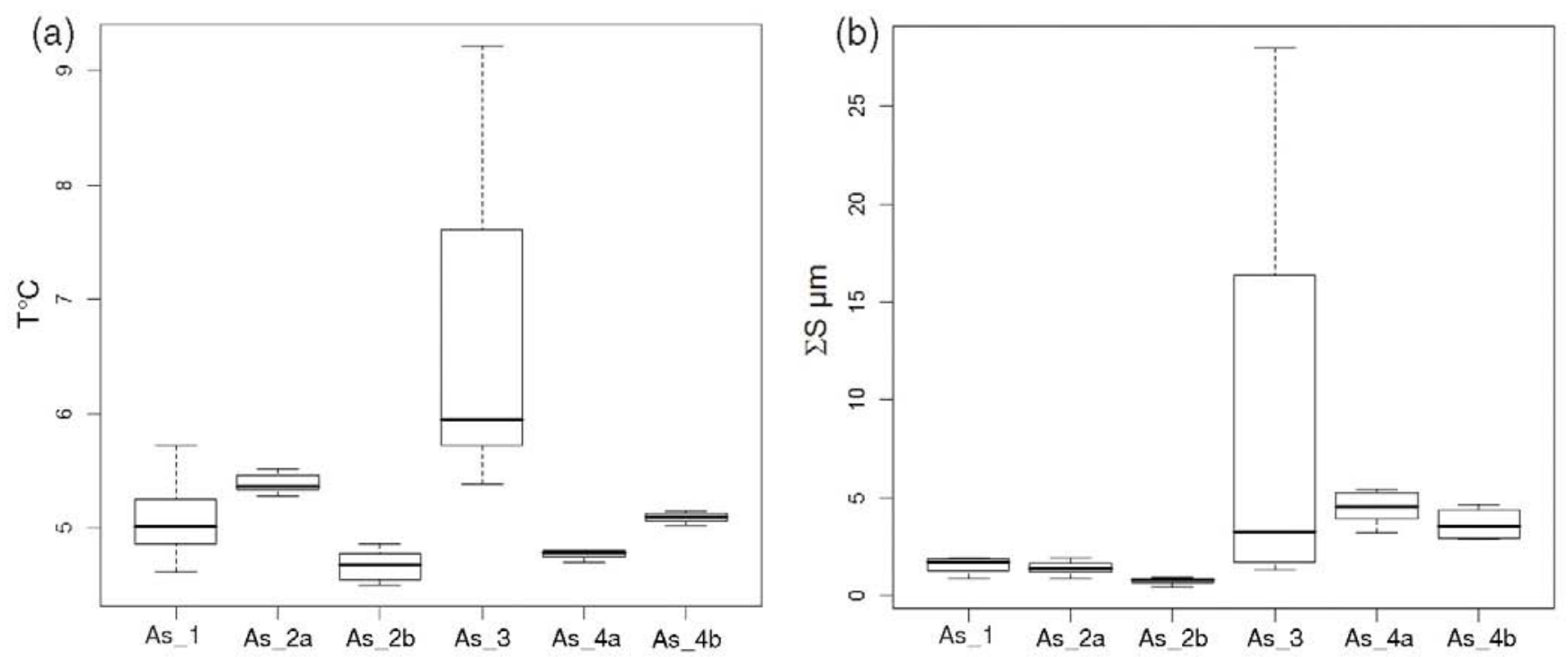

906 Fig. 4: Boxplots of environmental variables per assemblages. (a) Temperature and (b) $\sum S$

907 were measured in situ. Black horizontal lines within the boxes represent the median.

908

909

910

911

912

913

914

915

916

917

918

919

920

921

922

923

924

925

926

927

928

929

930

931

932

933

934

935

936

938 
१२०

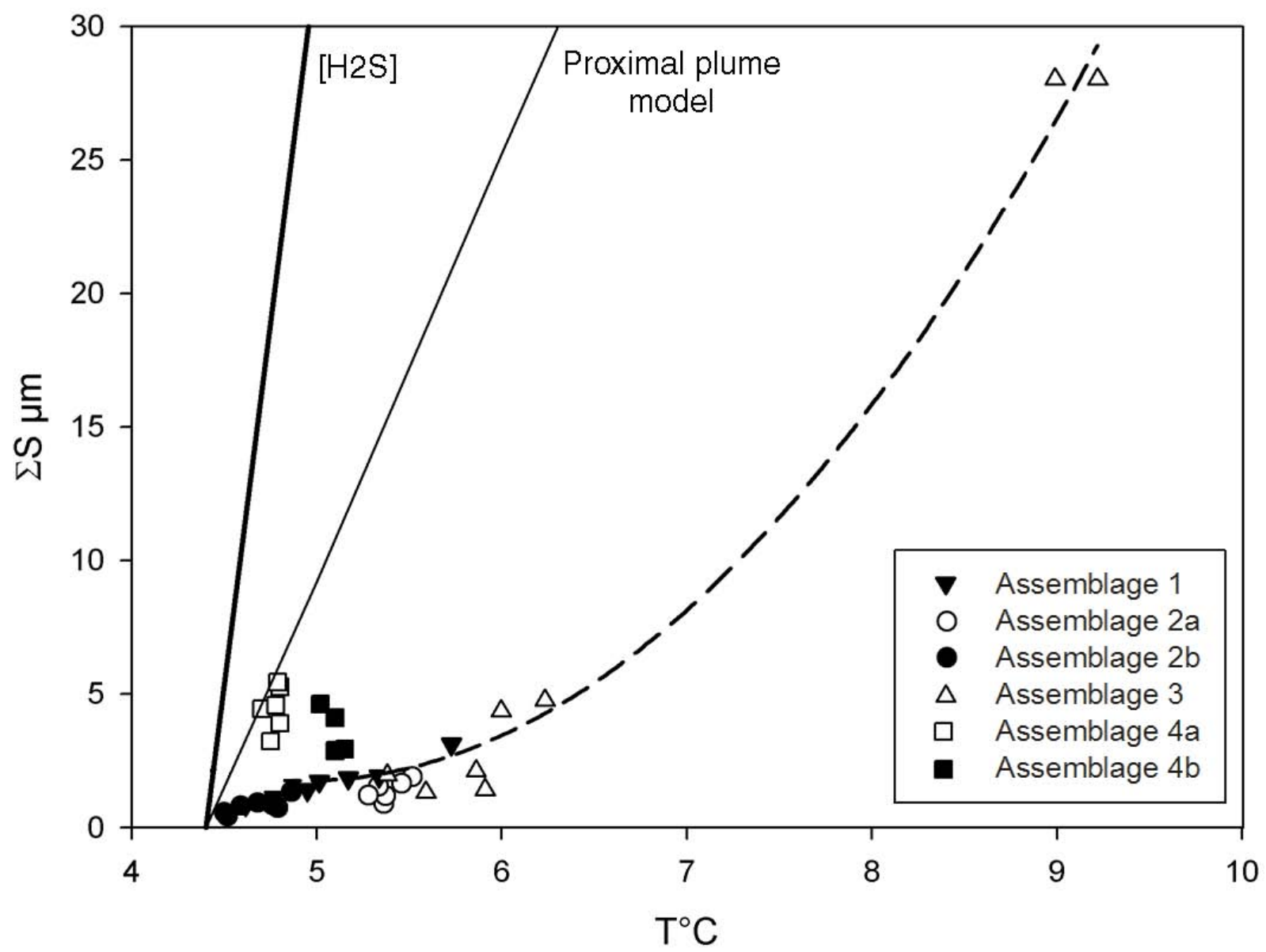

965 Fig. 5: Total sulfide concentration versus temperature on the different assemblages of the Eiffel Tower edifice. The curve between the assemblages is the best fitting polynomial curve $\left(\mathrm{R}^{2}=0.95\right)$ and can be considered as a non-linear dilution curve. $\left[\mathrm{H}_{2} \mathrm{~S}\right]$ is the theoretic sulfide value, based on the end-member fluid concentrations at Eiffel Tower (Charlou et al., 2000). The "proximal plume model” represents the $\mathrm{T}^{\circ} \mathrm{C}$ vs. $\sum \mathrm{S}$ values based on the measurements made on uncolonised areas, in the vicinity of a black smoker (Sarradin et al., in prep.). See Fig. 2 for assemblage identification. 
989

990

991

992

993

994

995

996

997

998

999

1000 ํ

1001 ㅁ

1002

1003

1004

1005

1006

1007

1008

1009

1010

1011

1012

1013

1014

1015

1016

1017

1018

1019

1020

1021

1022

1023

1024

1025

1026

1027

1028

1029

1030

1031

1032

1033

1034

1035

1036

1037

1038

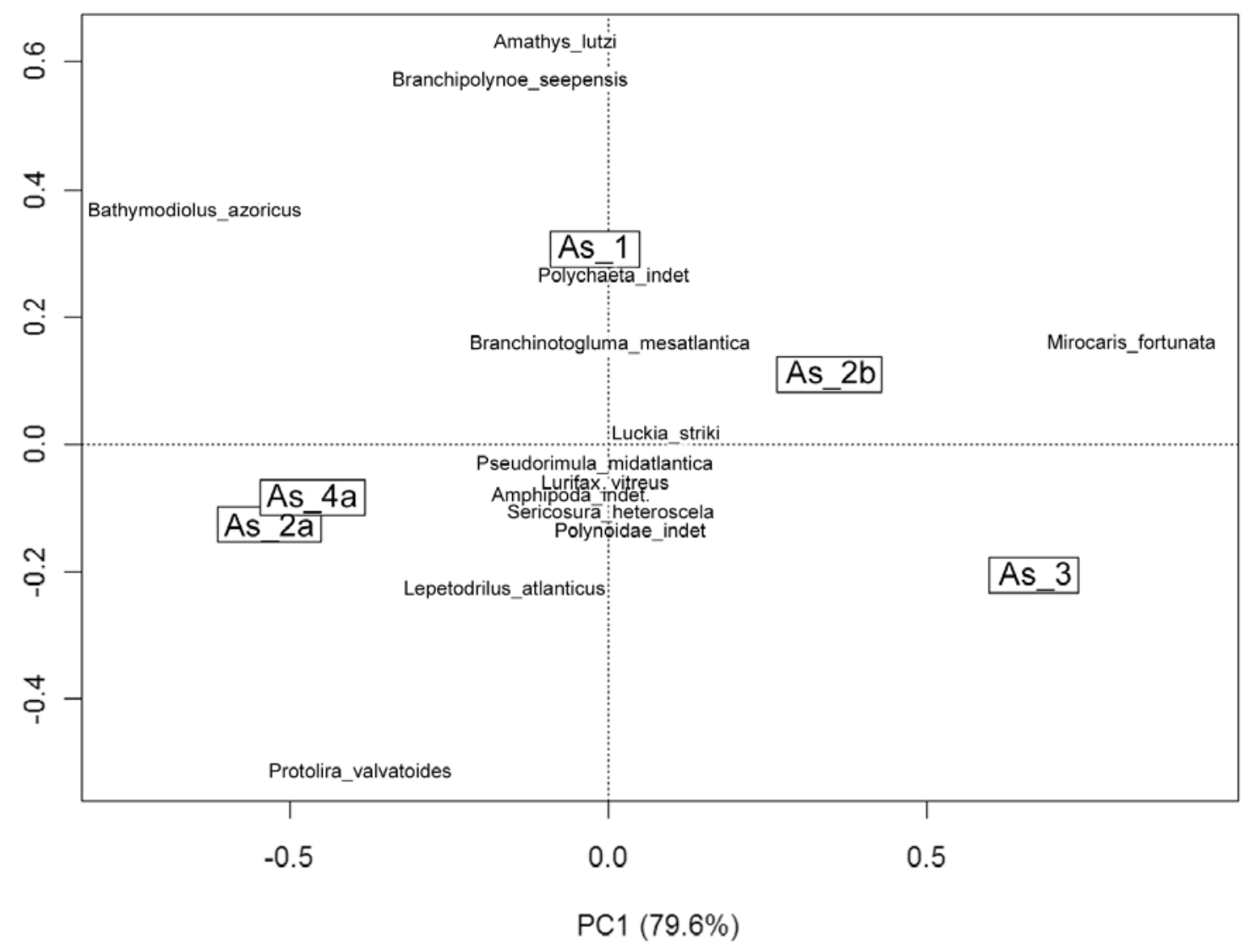

Fig. 6: Principle Components Analysis (PCA) based on the Hellinger transformed species abundance data. A total variation of $92.4 \%$ is explained by the PCA plot, where the first axis accounts for $79.6 \%$ and the second for $12.8 \%$. Ass=Assemblage. 


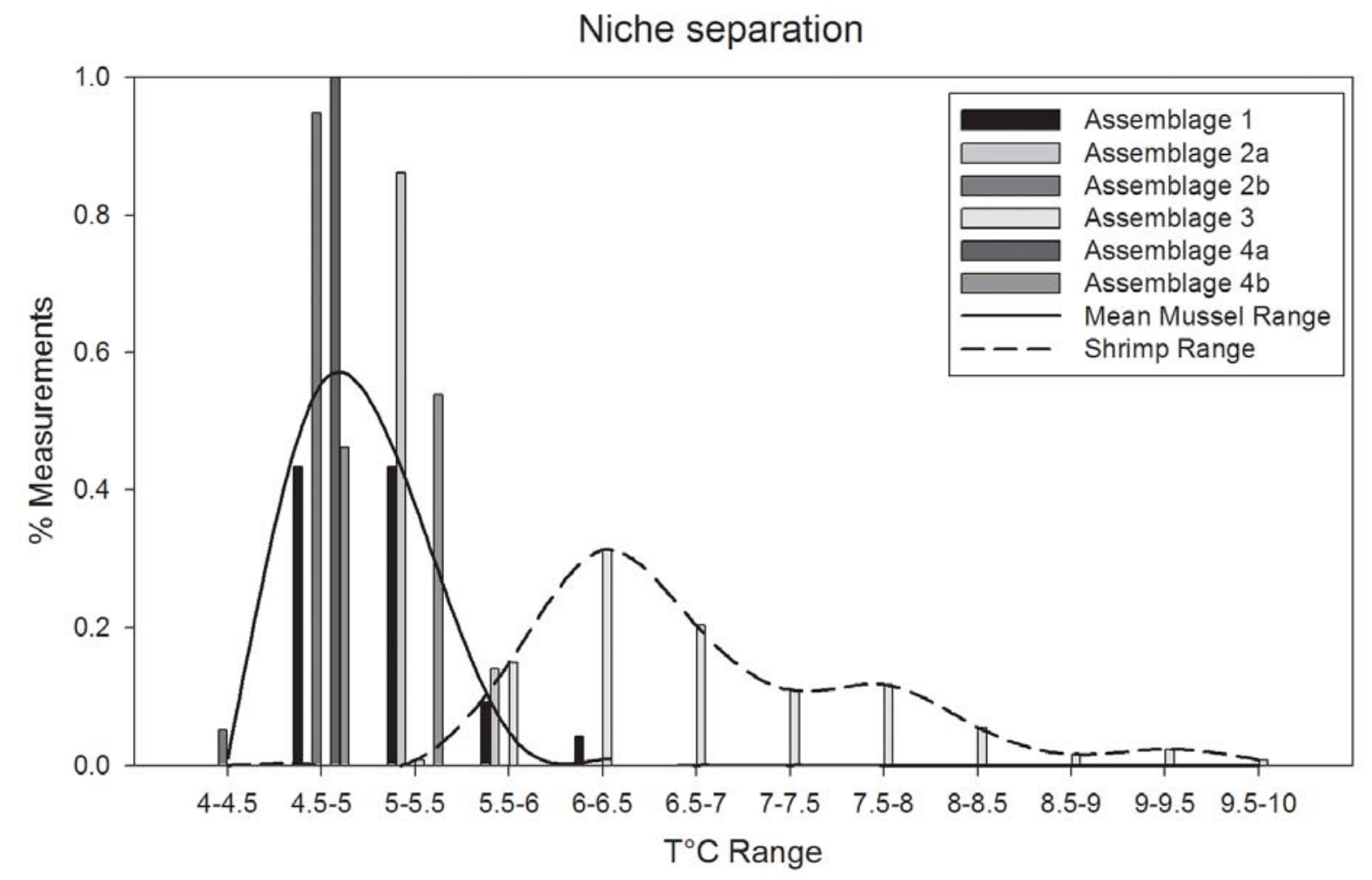

1041

1042

1043

1044

1045

1046

1047

1048

1049

1050

1051

1052

1053

1054

1055

1056

1057

1058

1059

1060

1061

1062

1063

1064

1065

Fig. 7. Histogram featuring the percentage of $\mathrm{T}^{\circ} \mathrm{C}$ measurements in $0.5^{\circ} \mathrm{C}$ intervals for each assemblage. Two temperature-niches are revealed, one for the mussel-based assemblages (mean frequency) of the mussel-based assemblages measurements) and the other for the shrimp assemblage.

1066 